\title{
Health Behaviors, Dietary Patterns and Physical Activity level of Physical Education Department Students in the State of Kuwait: A Cross-Sectional Study
}

\author{
Kazem Jaber Ghloum*, Abdulmajeed Mohamed Almousawi**
}

\begin{abstract}
:
A survey was conducted to obtain and compare health behaviors, diet habits and physical activity levels of Physical Education Department students in the State of Kuwait. In addition, a dietary consumption analysis was applied. Physical Education and Sports Performance Department at the College of Basic Education, the State of Kuwait, during September 2010 through January 2011 semester. A cross-sectional survey of one hundred twenty students, 60 males mean $\pm S D$ aged (20.2 \pm 2.1 years) and 60 females $(21.1 \pm 1.7$ years $)$, were randomly chosen from physical education department to participate in the present study. All students completed self-administered questionnaires about the students' cigarette smoking, level of physical activity, diet consumption, sleeping and eating habits. The weights and heights of all students were measured, from which the body mass index (BMI) was calculated. Also, a 24 hour dietary recall was used to determine the total and percentages daily caloric consumption, macronutrients and micronutrients intake. Identification of different health hazards such as tobacco smoking, passive smoking, leading a sedentary life style, high fat consumption especially saturated fat and negative dietary habits may help to direct the health officials in both private and governmental sectors to work together with college faculty in organizing health educational programs. In addition, the present study results suggest the necessity of developing nutrition and health promotion programs for the physical education department students, especially programs emphasizing healthy and balanced diet consumption and behavior.
\end{abstract}

\section{Introduction:}

$\mathrm{T}$ he Physical Education department of the College of Basic Education and several others colleges are under administrative managements of Public Authority for Applied Education and Training. Although, male and female students are in separate buildings, the curriculums offered are similar.

Health behaviors and dietary patterns have been a major concern for the Kuwaiti government and the neighboring Gulf Cooperation Council (GCC) countries since the discovery of the oil around 1933. It has been a transition in almost

\footnotetext{
* Associate Professor, Department of Physical Education and Sports, College of Basic Education, The Public Authority for Applied Education and Training, The State of Kuwait.

** Assistant Professor, Department of Physical Education and Sports, College of Basic Education, The Public Authority for Applied Education and Training, The State of Kuwait.
}

all aspects of life. Social lifestyles and eating habits are affected in many ways, mostly due to dependency on technology, house servants as well as the high per capita income $(29,66)$.

Tobacco smoking is a major health hazard and the most preventable cause of death in many countries. According to the World Health Organization (WHO), tobacco and its products kill over 3.5 million people worldwide every year and it is extrapolated that by 2020-2030, tobacco will kill approximately 10 million people a year (1). There are some 4000 known chemicals in tobacco smoke with at least 250 of them known to be harmful with more than 50 known carcinogens. Tobacco smoke, inhaled in poorly circulated spaces, exposes everyone (smokers and non-smokers alike) to its harmful effects (15). Exposures to these chemicals are referred to as involuntary smoking or passive smoking. Passive smokers absorb nicotine and other compounds just like smokers $(11,13)$. 
Smoking and passive smoking is associated with various types of cancers and serious cardiovascular and respiratory diseases including coronary heart disease and lung cancer $(2-10,14,16)$.

Memon et al. reported in 2000 (18), that there is greater than $39 \%$ of the overall Kuwaiti population and $50 \%$ of all high school students are smokers.

The 2011 World Health Organization report stated that $37.5 \%$ of the male and $49.8 \%$ of the female Kuwaiti population aged 15 to 55 years were obese. Also, $78.4 \%$ and $79.5 \%$ of male and female were overweight, respectively. Furthermore, the report revealed that $36.9 \%$ of males and $4.3 \%$ of females to be smokers, a high indicator of potential serious health problem (1).

Many studies reported a high correlation between dietary consumption and cardiovascular diseases among high school $(19,20)$ and college students $(21,22,24,25)$, as well as in the general population (23). Specifically the studies looked at diets high in saturated fat and cholesterol and low dietary fiber intake.

With the numerous reports on obesity rates and unhealthy smoking and dietary habits among the Kuwaiti population, detailed information regarding the health hazards of the population, specifically physical education students in the State of Kuwait, should be available. However, a review of scientific literature has revealed that there is not sufficient information.

In this study, the authors attempt to determine the health behaviors and nutritional hazards of Kuwaiti college students within the department of physical education. The Health behaviors and dietary patterns are categorized by the lack of physical activity, the consumption of an unbalanced diet and high caloric food intake, smoking, passive smoking and by skipped or irregular meal times. The information gathered can be used to identify the current nutritional status, nutrient deficiencies and health behaviors of college students. In addition, the authors hypothesis if the department curriculum enhances the students knowledge and awareness. As the results, recommending strategies and programs to help promote and maintain healthy active living will be suggested. (does not make sense) Therefore, the purpose of the present study was to obtain and compare information about health behaviors such as smoking, physical activity, eating habits and dietary consumption of male and female physical education students in the State of Kuwait in order to address health hazards and implement strategies accordingly.

\section{Subjects and Methods:}

One hundred twenty students (60 males and 60 females) from a total of 428 (28.0\%) enrolled in the Department of Physical Education and Sports at the Basic College of Education in the State of Kuwait for the fall semester 2010-2011 were randomly selected as subjects in the present study. The questionnaire was administered after a written approval from collage administration regarding the study. Student selection was carried out in the final week of exams after the purpose and methodology were explained. The questionnaire was then collected and reviewed by the authors to omit any ambiguous answers.

The authors developed a questionnaire consisting of 10 questions regarding the following 4 categories; subject's demographic characteristics, health behaviors, diet habits and physical activity level. Several copies of the questionnaire were answered by male and female students. The reliability and the internal consistency of the questionnaire were reviewed by several knowledgeable professors from the physical education department. The questionnaire was approved and a Cronbach's alpha coefficient was applied (an alpha value equal to or greater than 0.70 was considered satisfactory).

The mean \pm SD age of male and female students was $20.2 \pm 2.1$ and $21.1 \pm 1.7$ years, respectively. The weight and height of all subjects was measured using a medical scale (Detecto's ProHealth 6129 medical scale with height measurement rod).

Body mass index (BMI), which is the ratio of weight in kilograms to height in meters square, was used to assess body weight status. According to the National Institutes of Health $(\mathrm{NIH})$, adults were classified based on their 
BMI as underweight (BMI < 18.5), normal $(\mathrm{BMI}=18.5-24.9)$, overweight $(\mathrm{BMI}=25$ $29.9)$, or obese (BMI $\geq 30$ ) which is further divided to Class I (30.0 - 34.9), Class II (35.0 39.9) and Class III ( $\geq 40.0)$ (1).

Another anonymous questionnaire demographic information regarding age, sex, height, weight (body mass index), smoking behaviors (current smoker or passive, starting age of smoking, numbers of cigarettes smoked per day, smoking while on campus and any attempt to quit), physical activity (competitive, recreational or sedentary), department curriculum (physical fitness classes offered, if the theory of physical fitness and health nutrition classes provided information regarding health and nutrition), and finally eating habits (skipping certain meals, consumption and frequency of fast food per week).

To calculate the caloric requirement for Kuwaiti students, the basal metabolic rate (BMR) was calculated using the Harris Benedict equation (21). The formula encompassed factors of height, weight, age, and sex including the application of physical activity level of $1.5 \times$ $\mathrm{BMR}$. As a result, the mean caloric intake for male and female students was 2692.1 and 1846.3 calories/day, respectively.

In addition, a 24 hour dietary recall was conducted to estimate total daily caloric consumption. Macronutrient and micronutrient intake was compared to the American Recommended Daily Allowance (RDA).

The students recorded food and fluid intake as well as food portion sizes using household measures such as cups, dishes, spoons, brand names, type of cooking and weight of items consumed. Students were encouraged to be very specific and as accurate as possible in recording food consumption. In addition, the household measurements were demonstrated to all students to ensure accuracy.
After completion of the food consumption records, all data for the amount of macronutrient and micronutrient intake were entered carefully by the authors in the computer using Microsoft Windows 2000 with the software program (DINE Systems, Inc. 2009, DINE healthy 7, Whiteville, North Carolina). The print out of this software program is capable in producing an accurate caloric, macronutrient and micronutrient intake values of all subjects. All the food intake values measured were analyzed in both percentages and grams.

\section{Data Analysis:}

All statistical computations were performed using the Statistical Package for the Social Sciences (SPSSx Inc. Chicago, IL). Descriptive statistics are presented as means \pm standard deviations for all measurements. Dependent variables were health behaviors, diet habits and physical activity level and independent variables were Physical Education Department students.

Two single sample t-tests were applied to examine any significant differences between the mean values of caloric and macronutrient intake by weight and by percentage (Table 8 and 9) and micronutrient intake by weight (Table 11 and 12) of all subjects and then compared to normal values of the American Recommended Daily Allowances (RDA). It is important to mention that the RDA did not consider the athletes when food consumption was recommended. A P-value lower than or equal to 0.05 was accepted as a statistically significant.

\section{Results:}

Subjects for the present study, a total of one hundred twenty students (60 males and 60 females) from a total of 428 enrolled in the Physical Education Department at the Basic College of Education in the State of Kuwait for the year 2010-2011 were selected. 
Table (1)

Students (male/female) personal characteristics (mean $\pm S D)$

\begin{tabular}{|c|c|c|c|}
\hline Variables & P.E .Male Students & P.E .Female Students & $P$ value \\
\hline Age $(\mathrm{yr})$ & $20.2 \pm 2.1$ & $21.1 \pm 1.7$ & 0.02 \\
\hline Mean Body Mass $(\mathrm{Kg})$ & $68.8 \pm 11.2^{*}$ & $55.3 \pm 6.5^{*}$ & 0.00 \\
\hline Mean Height $(\mathrm{cm})$ & $173.7 \pm 7.6^{*}$ & $160 \pm 4.7^{*}$ & 0.00 \\
\hline Body Mass Index & $22.7 \pm 4.3$ & $21.6 \pm 2.3$ & 0.14 \\
\hline
\end{tabular}

$*(P \leq 0.05)$ significant differences between male and female students

Table 1 shows that the mean age of male and female students is $20.2 \pm 2.1$ and $21.1 \pm 1.7$ years. Mean body mass and height for male and female students was $68.8 \pm 11.2 \mathrm{~kg}$ and 55.3 $\pm 6.5 \mathrm{~kg}, 173.7 \pm 7.6 \mathrm{~cm}$ and $160 \pm 4.7 \mathrm{~cm}$, respectively.

There were significant differences $(P \leq 0.05)$ in mean body mass and mean height between male and female students.
Male students were typically taller, heavier and had higher BMI values than the female students. The standard weight status categories associated with BMI ranges for adults is between the values of 18.5 - 24.9. The male and female students in the present study are in normal range of $22.7 \pm 4.3$ and $21.6 \pm 2.3$ respectively.

Table (2)

Characteristic of smoking habits of male and female P.E students Numbers (No) and ( Percentages) (\%)

\begin{tabular}{|c|c|c|}
\hline Variables & P.E .Male Students & P.E .Female Students \\
\hline Smokers & $26(43.3 \%)$ & $4(6.6 \%)$ \\
\hline Passive smokers & $54(90 \%)$ & $26(43.3 \%)$ \\
\hline Starting age of smoking (yr) & $17.6 \pm 3$ & $16.4 \pm 3$ \\
\hline Numbers of smoked cigarettes per day & $16.7 \pm 7$ & $11.5 \pm 7$ \\
\hline On campus & $24(92.3 \%)$ & $1(25 \%)$ \\
\hline Smokers attempt to quit & $24(92.3 \%)$ & $2(50 \%)$ \\
\hline
\end{tabular}

Table 2 shows that the prevalence of smoking among the male physical education students was $43.3 \%$ for males and $6.6 \%$ for females. The male smokers smoked an average of $16.7 \pm 7$ cigarettes per day and females smoked $11.5 \pm 7$ per day. Of all students, there were $54(90 \%)$ passive male smokers and $26(43.3 \%)$ passive female smokers. The average onset of smoking was $17.6 \pm 3$ years of age and $16.4 \pm 3$ for males and females, respectively. Table 2 demonstrates a high percentage of male students smoking on campus $24(92.3 \%)$ and smokers attempting to quit $24(92.3 \%)$. On the other hand, only one $(25 \%)$ of the female students smoked while on campus and two (50\%) of the smokers attempted to quit.

Table (3)

Characteristic of physical activities of male (60) and female (60) P.E students: Competitive, recreational and sedentary life styles. (No. and Percentages)

\begin{tabular}{|c|c|c|}
\hline Variables & P.E .Male Students & P.E .Female Students \\
\hline Competitive Students & $8(13.3 \%)$ & $2(3.3 \%)$ \\
\hline Recreational Students & $12(20.0 \%)$ & $13(21.7 \%)$ \\
\hline Students with sedentary life style & $40(66.7 \%)$ & $45(75 \%)$ \\
\hline
\end{tabular}

Table 3 illustrates that $8(13.3 \%), 12(20.0 \%)$ and $40(66.7 \%)$ male students from a total of 60 led competitive, recreational or sedentary life styles, respectively. Also, 2 (3.3\%), 13 (21.7\%) and $45(75 \%)$ from a total of 60 female students led competitive, recreational and sedentary life styles, respectively. 
Table (4)

Patterns of eating habits of male and female P. E students. (Percentages)

\begin{tabular}{|c|c|c|}
\hline Variables & P.E .Male Students & P.E .Female Students \\
\hline Skipping Breakfast & $41(68.3 \%)$ & $35(58.3 \%)$ \\
\hline Skipping Lunch & $3(5 \%)$ & $5(8.3 \%)$ \\
\hline Skipping Dinner & $19(31.7 \%)$ & $30(50 \%)$ \\
\hline Consumption of fast food & $58(96.7 \%)$ & $50(83 \%)$ \\
\hline Consuming fast food less than 3/t/wk & $12(20.7 \%)$ & $34(68 \%)$ \\
\hline Consuming fast food more than 3/t/wk & $46(79.3 \%)$ & $16(32 \%)$ \\
\hline Curriculum provides sufficient physical activity & $22(36.6 \%)$ & $46(76.7 \%)$ \\
\hline Curriculum provides sufficient health and diet information & $25(41.6 \%)$ & $21(35 \%)$ \\
\hline
\end{tabular}

Table 4 illustrates some of the eating habits of male and female P.E students. $41(68.3 \%)$ and $35(58.3 \%)$ of male and female students skipped breakfast whereas, only $3(5 \%)$ male students and $5(8.3 \%)$ female students skipped lunch. Also, 19 male students (31.7\%) and 30 female students (50\%) skipped dinner. The number of students that consumed fast food were 58 (96.7\%) for males and $50(83 \%)$ for females, respectively. However, the number of male students who consumed fast food less than three times a week was $12(20.7 \%)$ and fast food consumed by male students more than $3 \mathrm{x} /$ week was $46(79.3 \%)$. On the other hand, female students who consumed fast food less than $3 \mathrm{x} /$ wk was $34(68 \%)$ and fast food consumed more than $3 \mathrm{x} /$ week was $16(32 \%)$ for females.

Male students were asked if the department curriculum provided sufficient physical activity throughout the day, and only $22(36.6 \%)$ of male students and $46(76.7 \%)$ of female students agreed, respectively. In addition, 25 $(41.6 \%)$ of male students and 21 (35\%) of female students believed that the curriculum incorporated sufficient health and diet information.

Table (5)

Mean caloric intake and the percentages of daily calories from carbohydrates, fat (saturated, monounsaturated and polyunsaturated) and protein for male Physical Education (P.E.) students (mean \pm SD)

\begin{tabular}{|c|c|c|c|}
\hline Variables & P.E .Male Students & $\begin{array}{c}\text { Daily RDA values according } \\
\text { to the calories consumed }\end{array}$ & $P$ value \\
\hline Calorie per day (day) & $2692.1 \pm 752.4$ & $2600-2800$ & .51 \\
\hline Carbohydrate (\%) & $43.9 \pm 9.3^{*}$ & $45-65$ & .01 \\
\hline Fat (\%) & $37.8 \pm 4.8^{*}$ & $20-35$ & .00 \\
\hline Saturated Fat (\%) & $16.4 \pm 3.2^{*}$ & $7-10$ & .00 \\
\hline Monounsaturated Fat (\%) & $14.1 \pm 3.0^{*}$ & $5-7$ & .00 \\
\hline Polyunsaturated Fat (\%) & $6.4 \pm 3.0$ & $5-7$ & .01 \\
\hline Protein (\%) & $17.8 \pm 6.3 *$ & $10-35$ & .00 \\
\hline
\end{tabular}

$*(P \leq 0.05)$ significant differences between male students diet consumption and RDA values.

The results in Table 5 illustrate mean caloric intake and the percentages of calories from carbohydrates, fat (saturated, monounsaturated and polyunsaturated) and protein based on the 24 hour dietary recall method in comparison to the recommended values reported by the American Recommended Daily Allowance (RDA). The mean intake of 55\% carbohydrates, $30 \%$ fat and $15 \%$ protein was calculated to obtain the exact percent of daily calories consumed from different foods.

There was no significant difference in daily caloric consumption $2692.1 \pm 752.4$ for male students. The students had significantly higher $(\mathrm{P} \leq 0.05)$ percentage dietary intake of fat $(37.8 \%)$ and protein $(17.8 \%)$ from the total daily caloric intake. In addition, the results showed a statistically significant difference of percentage 
of carbohydrate consumption (43.9 $\pm 9.3 \%$ ), fat $(37.8 \pm 4.8 \%)$, saturated fat $(16.4 \pm 3.2 \%)$, monounsaturated fat $(14.1 \pm 3.0 \%)$, and protein $(17.8 \pm 6.3 \%)$ in comparison to the American
RDA percentages of carbohydrate (45-65\%), fat (20-35\%), saturated fat (7-10\%), monounsaturated fat $(5-10 \%)$, and protein $(10-$ $35 \%)$, respectively.

Table (6)

Mean caloric intake and the percentages of calories from carbohydrates, fat (saturated, monounsaturated and polyunsaturated) and protein for Physical Education (P.E.) female students (mean $\pm S D)$

\begin{tabular}{|c|c|c|c|}
\hline Variables & P.E .Female Students & Daily RDA Values & $P$ value \\
\hline Calorie per day (day) & $1846.3 \pm 639.7 *$ & $2000-2200$ & .04 \\
\hline Carbohydrate $(\%)$ & $45.8 \pm 8.0$ & $45-65$ & .51 \\
\hline Fat (\%) & $38.5 \pm 6.4^{*}$ & $20-35$ & .00 \\
\hline Saturated Fat (\%) & $16.2 \pm 3.7^{*}$ & $7-10$ & .00 \\
\hline Monounsaturated Fat (\%) & $13.7 \pm 3.7 *$ & $5-7$ & .00 \\
\hline Polyunsaturated Fat $(\%)$ & $6.2 \pm 3.3$ & $5-7$ & .08 \\
\hline Protein $(\%)$ & $15.4 \pm 4.9 *$ & $10-35$ & .00 \\
\hline
\end{tabular}

As shown in Table 6, statistically significant differences $(\mathrm{P} \leq 0.05)$ in calories per day, percent fat, saturated fat, monounsaturated fat and percent protein intake from the total calories consumed daily by female students were observed.

The female students had daily caloric intakes of $1846.3 \pm 639.7$, which was below the normal range of 2000-2200 calories per day according to age, weight, and height. Also, when the Harris Benedict equation was utilized, the results showed female students should consume 2130.8 calories daily. Female students had a normal percentage of the total daily calories from carbohydrates $(45.8 \quad \pm 8.0 \%)$ and polyunsaturated fat $(6.2 \pm 3.3 \%)$.

In addition, the results illustrated statistically significant differences in percentage of fat consumption $(38.5 \pm 6.4 \%)$, saturated fat (16.2 $\pm 3.7 \%)$, monounsaturated fat $(13.7 \pm 3.7 \%)$, and protein $(15.4 \pm 4.9 \%)$ in comparison to the American RDA percentages of carbohydrates (45-65\%), fat (20-35\%), saturated fat (7-10\%), monounsaturated fat $(5-10 \%)$, and protein $(10-$ $35 \%$ ), respectively.

Table (7)

Comparison of mean caloric intake and the percentages of calories from carbohydrate, fat (saturated, monounsaturated and polyunsaturated) and protein for all Physical Education (P.E.) male and female students $($ mean $\pm S D)$

\begin{tabular}{|c|c|c|c|}
\hline Variables & P.E .Male Students & P.E .Female Students & P value \\
\hline Calorie per day & $2692.1 \pm 752.4^{*}$ & $1846.3 \pm 639.7^{*}$ & .000 \\
\hline Carbohydrate (\%) & $43.9 \pm 9.3^{*}$ & $45.8 \pm 8.0^{*}$ & .038 \\
\hline Fat (\%) & $37.4 \pm 4.8$ & $38.5 \pm 6.4$ & .295 \\
\hline Saturated Fat (\%) & $15.4 \pm 3.2$ & $16.2 \pm 3.7$ & .227 \\
\hline Monounsaturated Fat (\%) & $14.1 \pm 3.0$ & $13.7 \pm 3.7$ & .432 \\
\hline Polyunsaturated Fat $(\%)$ & $6.4 \pm 3.0$ & $6.2 \pm 3.3$ & .760 \\
\hline Protein $(\%)$ & $17.8 \pm 6.3$ & $15.4 \pm 4.9$ & .314 \\
\hline
\end{tabular}

* $(P \leq 0.05)$ indicates significant differences between male and female students.

Statistically significant differences of mean caloric intake and the percentages of calories from carbohydrate intake between male and female student were noted. There was no significant difference in percent of fat, saturated fat, monounsaturated fat, polyunsaturated fat and protein among male and female students. This is an indication that both students consumed diets rich in fat, saturated fat, monounsaturated fat, polyunsaturated fat and protein. 
Table (8)

Composition of diet and mean macronutrients intake by weight for Physical Education (P.E.) male students (mean $\pm S D)$

\begin{tabular}{|c|c|c|c|}
\hline Variables & P.E .Male Students & $\begin{array}{c}\text { Daily RDA values according } \\
\text { to the calories consumed }\end{array}$ & P value \\
\hline Total Carbohydrate $(\mathrm{g} / \mathrm{d})$ & $288.0 \pm 99.6^{*}$ & $302.8-437.4$ or $(370.2 \mathrm{~g} / \mathrm{d})$ & .00 \\
\hline Total Fat $(\mathrm{g} / \mathrm{d})$ & $110.6 \pm 30.2^{*}$ & $59.8-104.6$ or $(89.7 \mathrm{~g} / \mathrm{d})$ & .00 \\
\hline Saturated Fat $(\mathrm{g} / \mathrm{d})$ & $46.2 \pm 16.6^{*}$ & $20.9-29.9$ & .00 \\
\hline Monounsaturated Fat $(\mathrm{g} / \mathrm{d})$ & $42.2 \pm 13.5^{*}$ & $14.9-20.9$ & .00 \\
\hline Polyunsaturated Fat $(\mathrm{g} / \mathrm{d})$ & $17.9 \pm 7.7^{*}$ & $14.9-20.9$ & .00 \\
\hline Total Protein $(\mathrm{g} / \mathrm{d})$ & $118.6 \pm 52.1^{*}$ & 56 & .00 \\
\hline Cholesterol $(\mathrm{mg})$ & $474.7 \pm 313.7^{*}$ & $<300$ & .00 \\
\hline Dietary Fiber $(\mathrm{g})$ & $15.1 \pm 8.1^{*}$ & 38 & .00 \\
\hline
\end{tabular}

* $(P \leq 0.05)$ significant differences between male students diet consumption and $R D A$ values.

Table 8 illustrates the composition of diet and mean macronutrients intake by weight for male P.E. students. The daily carbohydrate RDA recommendation is between $45-65 \%$ or 302.8 $437.4 \mathrm{~g} / \mathrm{d}$. Based on the mean daily caloric intake of 2692.1 for male students, the total carbohydrate consumption was $288.0 \pm 99.6 \mathrm{~g} / \mathrm{d}$ which is less than the recommended values of $302.8-437.4 \mathrm{~g} / \mathrm{d}$.

In order to calculate the macronutrient intake by weight, the total daily calories consumed by the male subjects (2692.1) was multiplied by the mean percent of carbohydrate $(55 \%)$, fat $(30 \%)$ and protein (15\%), and then divided by 100 and multiplied by the number of calories per one gram consumed (4 for carbohydrate, protein and 9 for fat). Therefore, the total carbohydrate consumption, fat and protein were $370.2 \mathrm{~g} / \mathrm{d}$, $89.7 \mathrm{~g} / \mathrm{d}$ and $56 \mathrm{~g} / \mathrm{d}$, respectively.

There is no RDA recommendation for fat intake however, individuals should limit percentage fat to no more than $20-35 \%$ of total daily calories. Depending to the 2692.1 calories per day consumed by male students, the fat intake should be between 59.8-104.6 g/day. However, the total fat consumption was $110.6 \pm 30.2 \mathrm{~g} /$ day for male students, which is greater than the recommended RDA values. Furthermore, the saturated, monounsaturated and polyunsaturated fat intake was $46.2 \pm 16.6,42.2 \pm 13.5$ and 17.9 \pm 7.7 , respectively. These values are more than the recommended values provided by RDA.

Significant differences $(\mathrm{P} \leq 0.05)$ in total protein intake $(118.6 \pm 52.1)$ were noted which is twice as much as the recommended value of $56 \mathrm{~g} /$ day.

In addition, male students consumed a diet high in cholesterol $(474.7 \pm 313.7 \mathrm{~g} / \mathrm{d})$ and low in fiber $(15.1 \pm 8.1 \mathrm{~g} / \mathrm{d})$ in comparison to recommended values of less than $300 \mathrm{mg} / \mathrm{d}$ and $38 \mathrm{~g} / \mathrm{d}$, respectively. 
Table (9)

Composition of diet and mean macronutrient intake by weight for Physical Education (P.E.) female students (mean $\pm S D)$

\begin{tabular}{|c|c|c|c|}
\hline Variables & P.E .Female Students & $\begin{array}{c}\text { Daily RDA values according } \\
\text { to the calories consumed }\end{array}$ & P value \\
\hline Total Carbohydrate $(\mathrm{g} / \mathrm{d})$ & $206.4 \pm 71.1^{*}$ & $207.7-300.0(253.8 \mathrm{~g} / \mathrm{d})$ & .00 \\
\hline Total Fat $(\mathrm{g} / \mathrm{d})$ & $79.1 \pm 31.7^{*}$ & $41.0-71.8$ or $(61.5 \mathrm{~g} / \mathrm{d})$ & .00 \\
\hline Saturated Fat $(\mathrm{g} / \mathrm{d})$ & $33.2 \pm 13.9^{*}$ & $14.3-20.5$ & .00 \\
\hline Monounsaturated Fat $(\mathrm{g} / \mathrm{d})$ & $28.4 \pm 12.0^{*}$ & $10.2-14.3$ & .00 \\
\hline Polyunsaturated Fat $(\mathrm{g} / \mathrm{d})$ & $13.4 \pm 9.1^{*}$ & $10.2-14.3$ & .02 \\
\hline Total Protein $(\mathrm{g} / \mathrm{d})$ & $74.3 \pm 38.4^{*}$ & $46.1-161.5$ or $(69.2 \mathrm{~g} / \mathrm{d})$ & .00 \\
\hline Cholesterol $(\mathrm{mg})$ & $276.2 \pm 204.3$ & 300 & .37 \\
\hline Dietary Fiber $(\mathrm{g})$ & $11.3 \pm 5.3^{*}$ & 25 & .00 \\
\hline
\end{tabular}

* $(P \leq 0.05)$ significant differences between female students diet consumption and $R D A$ values.

Table 9 shows the composition of diet and mean dietary fiber and total protein intake (118.6 macronutrients intake by weight for P.E. female $\pm 52.1 \mathrm{~g} / \mathrm{d})$ which is higher than the students. There were significant differences $(\mathrm{P} \leq$ recommended value of $56 \mathrm{~g} / \mathrm{day}$. Only the value 0.05 ) in total carbohydrate, total fat, saturated of cholesterol intake $276.2 \pm 204.3 \mathrm{mg}$ fell fat, monounsaturated fat, polyunsaturated fat, within the normal range of $300 \mathrm{mg}$.

Table (10)

Comparison of diet composition and mean macronutrient intake by weight for all Physical Education (P.E.) male and female students (mean $\pm S D)$

\begin{tabular}{|c|c|c|c|}
\hline Variables & P.E .Male Students & P.E .Female Students & P value \\
\hline Total Carbohydrate g/d & $288.0 \pm 99.6^{*}$ & $206.4 \pm 71.1$ & .00 \\
\hline Total Fat g/d & $110.6 \pm 30.2^{*}$ & $79.1 \pm 31.7$ & .00 \\
\hline Saturated Fat & $46.2 \pm 16.6^{*}$ & $33.2 \pm 13.9$ & .00 \\
\hline Monounsaturated Fat & $42.2 \pm 13.5^{*}$ & $28.4 \pm 12.0$ & .00 \\
\hline Polyunsaturated Fat & $17.9 \pm 7.7$ & $13.4 \pm 9.1$ & .09 \\
\hline Total Protein $(\mathrm{g} / \mathrm{d})$ & $118.6 \pm 52.1^{*}$ & $74.3 \pm 38.4$ & .00 \\
\hline Cholesterol $(\mathrm{mg})$ & $474.7 \pm 313.7^{*}$ & $276.2 \pm 204.3$ & .00 \\
\hline Dietary Fiber $(\mathrm{g})$ & $15.1 \pm 8.1$ & $11.3 \pm 5.3$ & .07 \\
\hline
\end{tabular}

* $(P \leq 0.05)$ significant differences between male and female students diet composition of mean macronutrient intake.

Table 10 illustrates the comparison of diet macronutrient intakes except polyunsaturated composition and mean macronutrients intake by and fiber for both male and female students weight for male and female P.E. students. were observed.

Statistically significant differences in all 
Table (11)

Composition of mean micronutrient intake of male P.E students (mean $\pm S D)$

\begin{tabular}{|c|c|c|c|}
\hline Variables & P.E. Male Students & Daily U.S. RDA Values & P value \\
\hline Iron $(\mathrm{mg})$ & $15.4 \pm 6.4^{*}$ & 8 & .00 \\
\hline Calcium $(\mathrm{mg})$ & $777.8 \pm 560.5^{*}$ & 1000 & .03 \\
\hline Phosphorus $(\mathrm{mg})$ & $1418.2 \pm 466.9^{*}$ & 700 & .00 \\
\hline Sodium $(\mathrm{mg})$ & $4596.8 \pm 1978.6^{*}$ & $<2300$ & .00 \\
\hline Vitamin A (mcg) & $553.5 \pm 607.2^{*}$ & 900 & .00 \\
\hline Vitamin C (mg) & $65.8 \pm 69.1$ & 90 & .09 \\
\hline Vitamin D (mcg) & $12.5 \pm 4.7^{*}$ & 15 & .01 \\
\hline
\end{tabular}

$*(P \leq 0.05)$ significant differences between male students micronutrient consumption and RDA values.

Table 11 illustrates the composition of mean micronutrient intake of male P.E students. Significant differences $(\mathrm{P} \leq 0.05)$ were noted for iron $(15.4 \pm 6.4 \mathrm{mg})$, calcium (777.8 \pm 560.5 $\mathrm{mg})$, phosphorus $(1418.2 \pm 466.9 \mathrm{mg})$ and sodium intakes $(4596.8 \pm 1978.6 \mathrm{mg})$, in comparison to the daily RDA values of iron (8 $\mathrm{mg}$ ), calcium (1000 mg), phosphorus (700 mg) and sodium $(<2300 \mathrm{mg})$ respectively. In addition, significant differences $(\mathrm{P} \leq 0.05)$ for vitamin A $(553.5 \pm 607.2 \mathrm{mcg})$ and vitamin D $(12.5 \pm 4.7 \mathrm{mcg})$ were observed.

Table (12)

Composition of mean micronutrient intake of female P.E students (mean $\pm S D$ )

\begin{tabular}{|c|c|c|c|}
\hline Variables & P.E .Female Students & Daily RDA Values & P value \\
\hline Iron $(\mathrm{mg})$ & $10.9 \pm 5.2^{*}$ & $18 \mathrm{mg}$ & .00 \\
\hline Calcium $(\mathrm{mg})$ & $650.8 \pm 402.7^{*}$ & $1000(\mathrm{mg})$ & .00 \\
\hline Phosphorus $(\mathrm{mg})$ & $1072.9 \pm 466.2^{*}$ & $700(\mathrm{mg})$ & .00 \\
\hline Sodium $(\mathrm{mg})$ & $3305.4 \pm 2441.4^{*}$ & $<2300(\mathrm{mg})$ & .02 \\
\hline Vitamin A (mcg) & $553.5 \pm 627.9$ & $700 \mathrm{mcg}$ & .08 \\
\hline Vitamin C (mg) & $53.9 \pm 54.4^{*}$ & $75 \mathrm{mg}$ & .04 \\
\hline Vitamin D (mcg) & $11.5 \pm 3.4^{*}$ & $15 \mathrm{mcg}$ & .00 \\
\hline
\end{tabular}

Table 12 illustrates that significant differences $(\mathrm{P} \leq 0.05)$ were noted for iron $(10.9 \pm 5.2 \mathrm{mg})$, calcium (650.8 $\pm 402.7 \mathrm{mg}$ ), phosphorus (1072.9 $\pm 466.2 \mathrm{mg})$ and sodium intake (3305.4 \pm 2441.4 $\mathrm{mg}$ ) for female students in comparison to the

daily RDA values of iron (18mg), calcium $(1000 \mathrm{mg})$, phosphorus $(700 \mathrm{mg})$ and sodium $(<2300 \mathrm{mg})$, respectively. Also, there were significant differences $(\mathrm{P} \leq 0.05)$ for vitamin $\mathrm{C}$ $(53.9 \pm 54.4 \mathrm{mg})$ and vitamin $\mathrm{D}(11.5 \pm 3.4 \mathrm{mcg})$.

Table (13)

Comparison of composition of mean micronutrient intake of all P.E male and female students (mean \pm SD)

\begin{tabular}{|c|c|c|c|}
\hline Variables & P.E. Male Students & P.E .Female Students & P-value \\
\hline Iron $(\mathrm{mg})$ & $15.4 \pm 6.4^{*}$ & $10.9 \pm 5.2$ & .00 \\
\hline Calcium $(\mathrm{mg})$ & $777.8 \pm 560.5$ & $650.8 \pm 402.7$ & .18 \\
\hline Phosphorus $(\mathrm{mg})$ & $1418.2 \pm 466.9^{*}$ & $1072.9 \pm 466.2$ & .01 \\
\hline Sodium $(\mathrm{mg})$ & $4596.8 \pm 1978.6^{*}$ & $3305.4 \pm 2441.4$ & .02 \\
\hline Vitamin A mcg & $553.5 \pm 607.2$ & $553.5 \pm 627.9$ & 1.00 \\
\hline Vitamin C $(\mathrm{mg})$ & $65.8 \pm 69.1$ & $53.9 \pm 54.4$ & .33 \\
\hline Vitamin D $(\mathrm{mcg})$ & $12.5 \pm 4.7 *$ & $11.5 \pm 3.4$ & .00 \\
\hline
\end{tabular}

$*(P \leq 0.05)$ significant differences between male and female students diet composition of mean micronutrients intake

Table 13 shows the composition of mean

Micronutrient intake of P.E male and female 
students. There were significant differences in iron, phosphorus, sodium and vitamin D consumption between male and female students.

However, no statistically significant differences in calcium, vitamin $\mathrm{A}$, and vitamin $\mathrm{C}$ intake between male and female students were noted.

\section{Discussion:}

The most significant findings of the present study suggested students in the physical education department have several health hazards, an average body composition, an inactive lifestyle and unbalanced diet consumption. The diet is mostly comprised from fat; especially saturated fat that may have severe consequences. In addition, male students have higher smoking and passive smoking percentages than female students. It seems that the department curriculum did not enhance the students health and diet knowledge.

These negative behaviors may place Kuwaiti college students at increased risk for immediate and long-term health problems. The high percentage of smokers $(43.3 \%)$ and passive smokers (90\%) among male students and $(43.3 \%)$ among females suggests that a major epidemic of tobacco related diseases can be expected.

The main reason for the high percentage of passive male smokers over females is the traditional social life style where males attend social daily gathering club called "Dywania". Usually attended at night, there is no regulation of smoking in these places and as a result, all attending are exposed to cigarette smoke. In contrast, females do not attend this kind of social gathering. However, the percentage of both male and female passive smokers is high due to the fact that many people smoke in prohibited areas such as shopping malls, restaurants and hospitals without consequences. Therefore, the high percentage of passive smokers needs to be addressed through implementation of educational tools and measures to manage and reduce smoke exposure.

Tobacco smoking and unhealthy diet patterns established during youth may extend into later life and may increase the risk of cardiovascular diseases (CVD), cancer and other diseases $(12,17,28,29,31,32,33)$. In 1997, Eaton et al. (34) conducted a national school-based survey that revealed $36.4 \%$ of American high school students were smokers, $70.7 \%$ had inadequate diets and $72.6 \%$ were physically inactive. Dappen et al. (35) reported that $65 \%$ of high school students in the State of Virginia were smokers. Saeed et al. (36) found that $22 \%$ of secondary health students in Saudi Arabia were smokers. In the United Kingdom, two studies $(37,38)$ documented a smoking rate of $43 \%$ and $39 \%$ among student nurses and UK university students, respectively. In Japan, the percentage of smokers reached $46 \%$ among senior high school students. Hussain et al. (39) reported $11 \%$ of medical students in Pakistan were smokers.

In addition, a survey conducted by Assanelli et al. (41) for athletes and non-athletic students in northern Italy demonstrated a total of $23.3 \%$ and $30.9 \%$ were smokers, respectively. Even when an anti-smoking policy was introduced on campus, a study by Fiore et al. (42) concluded that $33 \%$ of the Madison-Wisconsin students were smokers.

The Center for Disease Control (CDC) (50) reported that $42.7 \%$ of American high school students were smokers. Also, the CDC stated in the 1991 Global Status Report that $52 \%$ of the Kuwaiti population was smokers and there was no future decline in this pattern.

Sugathan (52) stated in 1998 that Kuwaiti male university students initiated smoking between 16 - 17 years of age which corresponds with the present study subjects. In 1998, a study conducted by Moody et al (53), suggested that out of 1798 Kuwaiti male students and workers, $34.4 \%$ were classified as current smokers and $47.9 \%$ as non-smokers.

Memon (18) reported that the prevalence of smoking among Kuwaiti adults was $34.4 \%$ for males and $1.9 \%$ for females. Alansari (40) study in 2005 reported that $42.2 \%$ of Kuwaiti university male students were smokers out of 777 students surveyed. Another study by Almutairi (55) showed that $32.7 \%$ of males and $6 \%$ of female students in Riyadh (Saudi Arabia) Health Sciences College were smokers. A study by Al Hamdani et al. (66) in 2007 showed a 
high prevalence of smoking (40.6\%) among Kuwaiti adult males aged 18 years and older.

Also, a study by Labib (54) exhibited $35.2 \%$ of female Egyptian university students to be smokers. It appears from previous studies that the trend is similar for smoking among students. For example, the results in the present study showed an average of male student smokers to be $43.3 \%$ but shown to be much lower in female students $(6.6 \%)$. Furthermore, all previous studies were compared to the results of the present study. It may be noted that while smoking by Kuwaiti students falls within the range of other countries, the percentage of passive smokers is very high and may have devastating outcomes and consequences on future health (67).

In spite of the 1995 State of Kuwait law number 15 on smoking control and prohibition in public areas, there appears to be no governmental enforcement. A new governmental measure will be conducted for anti-smoking themes and will be introduced to school curriculums, family Medicine Consultant. The Secretary of the permanent committee for the national program for anti-smoking is hoping this will educate people and reduce the number of smokers and passive smokers.

The results of the survey also demonstrate a clear need for an anti-smoking cessation program in the Physical Education Department of Kuwait. Furthermore, there was sufficient data from the present study and others to alert the Ministry of Education and government officials about the health hazards present among students in Kuwait. Increased effort from governmental and non governmental agencies such as the Ministry of Education, Ministry of Public Health and Kuwait Society of Cancer and Smoking Prevention are needed to aid the students to overcome smoking and unhealthy eating habits.

The enrollment records show that a majority of male students in the Department of Physical Education are athletes who participate in various sport clubs. In contrast, the number of female student athletes is lower due to the lack of sporting club availability. However, both groups perform physical and recreational activities equally throughout the department curriculum.
Several investigations have demonstrated that physical inactivity has been linked to many diseases and obesity among college students in the USA $(43,44)$ and many other countries $(39,40,41,45,46,48)$. In the present study, $66.7 \%$ of male students and $75 \%$ of female students were inactive. This is a very high percentage since they are P.E. students. Female students requested more practical classes verses male students and both groups believe the department's curriculum provides sufficient health and diet information. However, not all students applied the new knowledge into their daily life in regards to adhering to a healthy life style and balanced diet.

In addition, when the American Recommended Daily Allowance (RDA) values were compared to the current subject's food values, a high fat content diet and low dietary fiber intake was recorded. Furthermore, the American Heart Association recommends limiting dietary fat to $30 \%$ of total calories (64). The high fat content in diets and low dietary fiber intake is associated with unhealthy eating habits that may increase the risk of coronary heart disease (CHD) and obesity (26). It should be noted that percentages recommended by RDA for fat and fiber consumption is the same for athletes and non-athletes. It may also be suggested that high consumption of calories is associated with many diseases such as CHD and diabetes (26).

The high cholesterol $(474.7 \pm 104 \mathrm{mg})$, high percentage of saturated fat $(37.4 \pm 4.8 \%)$ and low fiber $(15.1 \pm 8.1 \mathrm{~g} / \mathrm{d})$ consumed by male students is associated with an increased risk of (CHD). Also, female students are at risk due to the dietary consumption of high fat (79.1 $\pm 31.7)$, saturated fat $(33.2 \quad \pm 13.9)$, monounsaturated fat $(28.4 \quad \pm 12.0)$, polyunsaturated fat $(13.4 \pm 9.1)$, protein $(74.3$ $\pm 38.4)$, cholesterol $(276.2 \pm 204.3)$, and lower fiber $(11.3 \pm 5.3)$ intake. The percentage of male and female students who consumed fast food were $96.7 \%$ and $83 \%$, respectively. This may be a primary reason accounting for high fat intake, especially saturated fat and cholesterol, in their diet. $79.3 \%$ of male students consumed fast food more than three times per week in comparison to female students at $32 \%$. As a result, male students have a higher caloric intake per day due to the consumption of greater fat, protein 
and cholesterol. Frequent fast food eating can lead to obesity and CHD $(26,29)$.

One of the general concepts related to a healthy well balanced diet is eating breakfast, however, skipping breakfast was noted as an unhealthy pattern for male $68.3 \%$ and female $58.3 \%$ students in the present study. Eating breakfast provides energy for the different body systems to perform all physical and mental tasks required by the department curriculum. It also aids to prevent obesity $(57,58,59,60,61,62)$.

As the result of the above problems, in 2008, the Ministry of Health in Kuwait reported that $43.1 \%$ and $30.4 \%$ of males and $34.3 \%$ and $37.8 \%$ of females in the general population were overweight, and obese, respectively. The report added that $3.5 \%$ of males and $4.8 \%$ of females were morbidly obese (65).

According to national institute of health, the normal BMI ranges between 18.5-24.9, however, in the present study, the mean BMI for the male and female students were 22.7 and 21.6 respectively. Even though male and female students were within normal weight ranges according to BMI results, authors recommend a calculation based on a percentage body fat as it is a more reliable measure of actual amount of body fat. Also, female students should increase their daily caloric intake due to the demand of the physical activities in the department's curriculum as well as body's needs.

It is well documented that carbohydrate consumption provides the necessary energy to all body systems and since the students are very active throughout the day, they require an adequate amount of carbohydrates (49). Students in this study had higher fat, protein and less carbohydrate consumption than the values recommended by the American RDA. This result may have a major consequence in overall health and future heart related problems. $(27,30,56)$.

Physical education students need to consume a balanced diet to provide adequate energy for various body systems and to supply enough energy for physical activities. Several studies showed that the students who did not consume adequate diets were affected in their physical and mental activities throughout the day (47).
Physical education students should be role models for other students and parents since they, in turn, will teach physical education after graduation in elementary and secondary schools. More nutritional curriculums are required to educate students regarding the effects of good healthy eating habits and balanced diets in their life. Identification of the different health behaviors and hazards may also help to emphasize various methods in solving the problem and emphasize the need for antismoking education programs. Unfortunately, the college administration does not enforce the government's non-smoking policy.

\section{Limitations:}

There were few the limitations that understood when conducting this study such as subjects' cooperation was needed for obtaining accurate data and difficulties controlling the subject's dietary and health behavior, such as smoking and drinking.

\section{Conclusions:}

The following implementations and recommendations are suggested by the authors in accordance with the Centers for Disease Control and Prevention (CDC) guidelines of health programs (50):

1. Engage the Ministry of Health and Education officials, teachers, students, parents and the community in an effort to ensure healthier and smoke free environments for hospitals and schools;

2. Implementation of policies and taking measures that encourage better health habits;

3. Construct and implement new courses with emphasis on cardiovascular risk factors and physical fitness; it is necessary to develop a nutrition education program based on gender differences;

4. Joint efforts by governmental and nongovernmental organizations to enforce the 1995 anti-smoking law and to educate students about health hazards;

5. Smoking cessation programs should be introduced among Kuwaiti students to reduce 
the number of smokers and to promote awareness about second hand smoke;

6. Develop, implement and evaluate a tobaccocontrol program in order to make necessary changes were applicable;

7. Raise awareness of the health problems associated with cardiovascular disease among students;

8. Provide an environment that supports and maintains health promotion behaviors on campus;

9. Encourage community efforts to address risk factors, prevalence and disease prevention by using the various media such as television, computer internet and newspapers;

10. Encourage and increase physical activity levels among the female student population on campus;

11. Establish a school cafeteria where a variety of healthy and nutritional food is served at reasonable prices;

12. Encourage students to consume a selection of healthy food and more balanced diet;

13. Encourage students to not skip the breakfast meal;

14. Improve and update department health curriculum;

15. More practical classes should be offered by the department for both male and female students;

16. Participation in different physical fitness program outside the department curriculum offered by government or private sectors.

\section{Acknowlegment:}

The authors would like to thank all the students who participated in this study.

\section{References:}

1. World Health Organization (WHO), Noncommunicable disease, country profiles. 2011.

2. Lloyd-Jones D, Adams RJ, Brown TM. Heart Disease and Stroke Statistics - 2010 Update. A Report From the American Heart Association. Circulation 2011; 121:e46-e215.
3. Lightwood JM,. Coxson PG, BibbinsDomingo k, Williams LW, Goldman L. Coronary heart disease attributable to passive smoking: Am J Prev Med. 2009; 36:13-20.

4. Schwartz AG, Prysak GM, Bock CH, Cote ML. The molecular epidemiology of lung cancer. Carcinogenesis 2007; 28:507-18.

5. Centers for Disease Control and Prevention. Cigarette smoking among adults and trends in smoking cessation-United States, 2008. MMWR Morb Mortal Wkly Rep. 2009; 58:1227-32.

6. American Cancer Society. Cancer Facts \& Figures 2010. Atlanta, Ga.

7. Glynn T, Seffrin JR, Brawley OW, Grey N, Ross H. The globalization of tobacco use: 21 challenges for the 21 st century. Cancer J Clin. 2010; 60:50-61.

8. US Department of Health and Human Services. The Health Consequences of Smoking: A Report of the Surgeon General. Atlanta, Ga: USDHHS, Public Health Service, Centers for Disease Control and Prevention, National Center for Chronic Disease Prevention and Health Promotion, Office on Smoking and Health; 2006.

9. Gianicolo EAL, Cresci M, Ait-Ali L, Foffa I, Andreassi MG. Smoking and congenital heart disease: The epidemiological and biological link. Curr Pharm Des. 2010; 16:2572-2577.

10. Institute of Medicine. Secondhand Smoke Exposure and Cardiovascular Effects: Making Sense of the Evidence Washington, DC: The National Academies Press; 2010.

11. George D. Effect of passive smoking on health. BMJ 2003; 326:1048-1049.

12. Barnoya J, Glantz SA. Cardiovascular effects of secondhand smoke: nearly as large as smoking. Circulation 2005; 111:2684-2698.

13. Kawachi I. More evidence on the risks of passive smoking. BMJ. 2005; 330:265-266.

14. Pechacek TF, Babb S. How acute and reversible are the cardiovascular risks of secondhand smoke? BMJ. 2004; 328:980-983.

15. Collishow N, Lopez A. The tobacco epidemic: a global public health emergency. Tobacco Alert 1996; Geneva, WHO. 
16. Ezzati M, Henley SJ, Thun MJ, Lopez AD. The role of smoking in global and regional cardiovascular mortality. Circulation 2005; 112:489-97.

17. Harry A Lando H, Hipple B, Muramoto M, Klein J, Prokhorov A, Ossip D, Winickoff J. Tobacco is a global pediatric concern. Bull World Health Organ; 88:1, Genebra, Jan 2010.

18. Memon A, Moody PM, Sugathan TN, elGerges N, al-Bustan M, al-Shatti A, al-Jazzaf H. Epidemiology of smoking among Kuwaiti adults: prevalence, characteristics, and attitudes. Bull World Health Organ. 2000; 78:1306-1315.

19. Savige G, Ball K, Worsley A, Crawford D. Food intake patterns among Australian adolescents. Asia Pac. J. Clin. Nutr. 2007; 16:738-747.

20. Munzo K, Krebs-Smith S, Ballard-Barbash $\mathrm{R}$, Cleveland L. Food intakes of US children and adolescents compared with recommendations. Pediatrics 1997; 100:323329.

21. Kolodinsky J, Harvey-Berino J, Berlin L, Johnson R, Reynolds T. Knowledge of current dietary guidelines and food choice by college students: better eaters have higher knowledge of dietary guidance. J. Am. Diet Assoc. 2008; 107:1409-1413.

22. Huang T, Harris K, Lee R, Nazir N, Born W, Kaur H. Assessing overweight, obesity, diet and physical activity in college students. J. Am. Coll. Health. 2003; 52:83-86.

23. Vischedijk J, Simeant S. Targets for health all in 21st century, World Health Stat Q 1998; 51:56-67.

24. Yahia N, Achkar A, Abdullah A, Rizk S. Eating habits and obesity among Lebanese university students. Nutr J. 2008; 7:32.

25. Arroyo M, Rocandio AM, Ansotegui L, Pascual E, Salces I, Rebato E. Diet quality and obesity in university students. Nut Hospt. 2006; 21:673-679.

26. Romaina I, Anand S, Ounpuu S, Islam S, Zhang X, Rangarajan S, Chifamba J, Al-Hinai A, Keltai M, Yusuf S. Dietary patterns and the risk of acute Myocardial Infarction in 52 countries. Results of the INTERHEART study. Circulation 2008; 118:1929-1937.
27. Ko MS. The comparison in daily intake of nutrients, dietary habits and body composition of female college students by body mass index. Nutr Res Pract. 2007; 1:131-142

28. Lawrence J. Dietary patterns and longevity. Circulation 2008; 118:214-215.

29. Schroder H, Fito M, Covas MI. Association of fast food consumption with energy intake, diet quality, body mass index and the risk of obesity in a representative Mediterranean population. Br. J Nutr. 2007; 98:1274-1280.

30. Al-Isa AN. Obesity among Kuwait University students: an explorative study. Perspectives in Public Health 1999; 119:223227.

31. Post GB, Kemper HC, Twisk J, Van Mechelen $\mathrm{W}$. The association between dietary pattern and cardio vascular disease risk indicators in healthy youngsters: results covering fifteen years of longitudinal development. Eur J Clin Nutr. 1997; 51:387393.

32. Ellickson PL, Tucker JS, Klein DJ. Reducing early smokers' risk for future smoking and other problem behavior: insight from fiveyear longitudinal study. J. Adolesc Health. 2008; 43:394-400.

33. McGill HC. Nutrition in early life and cardiovascular disease. Curr Opin Lipidol. 1998; 9:23-27.

34. Eaton D, Kann L, Kinchen S, Shanklin S, Ross J, Hawkins J, Harris W, Lowry R, McManus T, MS, Chyen D, Lim C, Whittle L, Brener N, Wechsler H. Youth Risk Behavior Surveillance - United States, 2009. Surveillance Summaries. June 4, 2010 / 59(SS05);1-142.

35. Dappen A, Schwartz R, Odonnell. A survey of adolescent smoking patterns. J Am Board Fam Pract. 1996; 9:7-13.

36. Saeed A, Aljohali E, Alshary. Smoking habits of students in secondary health institutes in Riyadh City, Saudi Arabia. J R Soc Health. 1993; 113:132-135.

37. Carmichael A, Cockroft A. Survey of student nurses' smoking habits in a London teaching hospital. Respi Med. 1999; 84:277282. 
38. Webb E, Ashton H, Kelly P, Kamali F. Patterns of alcohol consumption, smoking and illicit drug use in British University students: interfaculty comparison. Drug Alcohol Depend 1997; 47:145-153.

39. Hussain S, Moid I, Khan J. Attitudes of Asian medical students towards smoking. Thorax 1995; 50:996-997.

40. Alansari BM. Prevalence of cigarette smoking among Kuwait University Undergraduate male students. Psychol Rep. 2005; 96:1009-1010.

41. Assanelli D, Donato F, Marconi M. Smoking habits and sporting activity among adolescent in north Italy. Rev Epidemiol Sante Publique. 1991; 39:457-465.

42. Fiore M, Jorenby D, Wetter D. Prevalence of daily and experimental smoking among University of Wisconsin-Madison undergraduate, 1989-1993. Wis Med J. 1993; 92:605-608.

43. Desai M, Miller W, Staples B, Bravender T. Risk factors associated with overweight and obesity in college students. J. Am. Coll. Health. 2008; 57:109-114.

44. Buckworth J, Nigg C. Physical activity, exercise and sedentary behavior in college students. J Am Coll Health. 2008; 57:28-34.

45. Irwin J. Prevalence of university students' sufficient physical activity: a systematic review. Precept. Mot. Skills. 2004; 98:927-934.

46. Irwin J. The prevalence of physical activity maintenance in a sample of university students: a longitudinal study. J. Am. Coll. Health. 2008; $56: 37-41$.

47. Hanning Rm, woodruff SJ, Lambraki I, Jessup L, Driezen P, Murphy CC. Nutrition intakes and food consumption pattern among Ontario students in grades six, seven and eight. Can J Public Health. 2007; 98:12-16.

48. Kromhout D, Epidemiology of cardiovascular diseases in Europe. Public Health Nutr. 2001; 4:441457.

49. Burke LM, Hawley JA. Fat and carbohydrate for exercise. Curr Opin Clinical Nutr Metab Care. 2006; 9:476-481.
50. Centers for Disease Control. Tobacco use among high school students- United States, 1997. MMWR 1998; 47:229-233.

51. Institute of Medicine, Food and Nutrition Board. Dietary reference intakes for calcium and vitamin D. Washington, DC: National Academy Press, 2010.

52. Sugathan TN, Moody PM, Bustan MA, Elgeres NS. Age pattern of smoking initiation among Kuwait university male students. Soc Sci Med. 1998; 47:1855-1858.

53. Moody PM, Memon A, Sugathan TN, Elgeres NS, Bustan MA. Factors associated with the initiation of smoking by Kuwaiti males. J Subst Abuse. 1998; 10:375-384.

54. Nargis L, Ghada R, Nabiel M, Mohamed M, El Setouhy M, Loffredo C, Israel E. Comparison of cigarette and water pipe smoking among female university students in Egypt. Nicotine Tob Res. 2007; 9:591-596.

55. Almutairi KM. Tobacco Prevalence among Health Sciences College Students (HSC) : Riyadh, Saudi Arabia. World family medicine J. 2010; 8:10-14.

56. Al-Rethaiaa AS, Fahmy AE, Al-Shwaiyat NM. Obesity and eating habits among college students in Saudi Arabia: a cross sectional study. Nutr J. 2010; 9:39.

57. Behbehani NN, Hamaden RR, Macklai NS. Knowledge and attitudes towards tobacco control among smoking and non-smoking physician in 2 Gulf Arab states. Saudi Med J. 2004; 25:585-591.

58. Agostoni C, Brighenti F. Dietary choices for breakfast in children and adolescent. Crit Rev Food sci Nutr. 2010; 50:120-128.

59. Keski-Rahkonen A, Kaprio J, Rissanen A, Virkkunen M, Rose RJ. Breakfast skipping and health comprising behaviors in adolescents and adults. Eur J Clin Nutr. 2003; 57:842-853.

60. Veltaista A, Laitinen J, Sovio U, Roma E, Jarvelin MR, Bakoula C. Relationship between eating behavior, breakfast consumption, and obesity among Finnish and Greek adolescents. J Nutr Educ Behav. 2010; 42:417-421.

61. C-J Huang, H-T Hu, Y-C Fan, Y-M Liao, P$\mathrm{S}$ Tsai. Associations of breakfast skipping with obesity and health-related quality of life: 
evidence from a national survey in Taiwan. Inter J Obes. 2010; 34:720-725.

62. Timlin MT, Pereira MA, Story M, Neumark-Sztainer D. Breakfast eating and weight change in a 5-year prospective analysis of adolescents: Project EAT (Eating Among Teens). Pediatrics 2008; 121:e638-e645.

63. El-Sabban F,.Badr HE. Assessment of nutrition knowledge and related aspects among first-year Kuwait university students. Ecol Food Nutr. 2011; 50:181-195.
64. American Heart Association's Dietary Guidelines for Heart Diseases and Stroke, 2011.

65. Ng SW, Zaghloul S, Ali HI, Harrison G, Popkin BM. The prevalence and trends of overweight, obesity and nutrition-related noncommunicable diseases in the Arabian Gulf States. Obes Rev. 2011; 12:1-13.

66. Al Hamdan AS, Al Ali SM, Al Mansour SM, Al Terkit A, Radwan M. The economic impact of smoking on the health system in Kuwait. KMJ. 2007; 39:120-125. 